\title{
(Sub)representação política feminina e a participação das mulheres em espaços democráticos: examinando conselhos públicos
}

\begin{abstract}
Female political (under)representation and the participation of women in democratic spaces: examining public councils
\end{abstract}

\author{
Lígia Maria Silva Melo Casimiro \\ Ana Cristina Aguilar Viana ${ }^{2}$ \\ Letícia Regina Camargo Kreuz ${ }^{3}$
}

Resumo: $\mathrm{O}$ artigo parte da observação acerca das diferenças historicamente estabelecidas entre ho-

1 Doutora em Direito Econômico e Desenvolvimento pela PUC/PR; Mestre em Direito do Estado pela PUC/SP; Professora do Departamento de Direito Público da UFC; Presidente do ICDA e Coordenadora de Pesquisa e Ensino do IBDU.

2 Doutoranda em Direito do Estado e Mestra em Políticas Públicas pela Universidade Federal do Paraná. Pesquisadora voluntária do Núcleo de Investigações Constitucionais (NINC-UFPR). Presidenta do Instituto Política por.de.para Mulheres.

3 Doutoranda e Mestra em Direito do Estado pela Universidade Federal do Paraná. Pesquisadora voluntária do Núcleo de Investigações Constitucionais (NINC-UFPR). Vice-presidenta do Instituto Política por. de.para Mulheres. Professora de Direito Constitucional do UNIBRASIL. 
mens e mulheres no campo social, evidenciando a baixa representatividade das mulheres em espaços de poder, algo contestado pelo movimento feminista, que almeja a ampliação do papel da mulher na dimensão política, bem como a ampliação de direitos e a isonomia no tratamento da mulher na sociedade. Nessa perspectiva, o objetivo do trabalho é abordar a sub-representação feminina na política, bem como examinar a qualidade da participação de mulheres nos espaços democráticos, em especial em Conselhos gestores públicos. A metodologia é lógica dedutiva. O trabalho se inicia com a construção histórico-social do papel da mulher na sociedade e perpassa as questões relativas ao movimento feminista. Em seguida, aborda a instrumentalização da participação social no Brasil, evidenciando a representação feminina nesses espaços, enfocando nos Conselhos gestores Públicos. Conclui-se que, ainda que tenha ocorrido relevante avanço para as mulheres no espaço público com sua crescente inserção em Conselhos locais, a arena pública ainda é majoritariamente masculina, evidenciando-se, ainda, que os espaços ocupados pelas mulheres possuem intrínseca relação com questões domésticas.

Abstract: The article starts from the observation about the historically established differences between men and women in the social field, evidencing the low representativeness of women in spaces of power, something disputed by the feminist movement, which aims to expand the role of women in the political dimension, as well as expansion of rights and equality in the treatment of women in society. From this perspective, the objective of this paper is to address women's under-representation in politics, as well as to examine the quality of women's participation in democratic spaces, especially in public management councils. The methodology is logical-deductive. The work begins with the historical and social construction of the role of women in society and crosses the issues related to the feminist movement. It then discusses 
the instrumentalization of social participation in Brazil, highlighting the female representation in these spaces, focusing on the Public Management Councils. It is concluded that, although there has been significant progress for women in the public space with its increasing insertion in local councils, the public arena is still mostly male, showing also that the spaces occupied by women are intrinsically related to domestic issues.

Sumário: 1. Introdução. 2. A construção do homem público e da mulher privada.3. Representação política e o feminismo. 4. Do processo de instrumentalização da participação social no Brasil. 5. A representação feminina nos espaços participativos, com enfoque nos Conselhos. 6. À guisa de conclusões: ainda o homem no espaço público e a mulher no espaço privado. 7 . Referências.

\section{Introdução}

A ideia de mulheres inseridas no campo político é atualíssima de um ponto de vista histórico. Por muitos séculos, foram elas reduzidas ao doméstico, ao privado, à família, à noção de beleza e de feminilidade. A justificação das diferenças sociais a partir de diferenças físicas permeia a realidade; a concepção do homem como detentor da força física, da virilidade, bravura, proteção e outros elementos de suposta superioridade do masculino sobre o feminino - esse, então, relacionado à delicadeza, fragilidade, fraqueza.

O homem seria, nessa visão, o ser adequado às tarefas públicas, ao campo externo ao ambiente doméstico (esse, sim, exclusivo da mulher e de seu amplo domínio). Ao homem caberia o trabalho fora de casa, à mulher o trabalho doméstico; ao homem a vida pública, a política, a representação; à mulher o recolhimento, a casa, a família, os filhos, nunca o espaço público. 
A partir do desenvolvimento do feminismo enquanto luta pela emancipação e igualdade da mulher, tais ideias passam a ser contestadas. As mulheres se ocupam em tomar o espaço público, em se fazer representar e reivindicar seus direitos fundamentais. Ainda assim, há uma dificuldade em assumir o espaço público e uma evidente sub-representatividade. Ainda que sejam metade da população, não alcançam no Legislativo números expressivos de representantes do gênero feminino.

O objetivo desse ensaio é, portanto, trabalhar com a ideia de representação feminina, partindo-se da exclusão da mulher do espaço público, passando pela mudança epistemológica evidenciada com o feminismo e com o início da inclusão feminina no espaço público e de reivindicações de direitos fundamentais. O passo seguinte é abordar a representação política, a sua relação com o feminismo e chegar então ao processo de instrumentalização da participação social no Brasil. Por fim, será abordada a participação da mulher nos espaços de participação social e as mudanças sociais daí decorrentes.

O enfoque será na participação feminina em Conselhos Gestores locais, onde se identificou forte presença, predominantemente na área social. A metodologia aplicada é lógica dedutiva, mediante descrição da literatura encontrada sobre o tema, seguida de análise crítica dos resultados identificados pela literatura.

\section{A construção do homem público e da mulher privada}

Homens e mulheres assumem historicamente posições sociais distintas. A dissimetria na relação denota a 
manutenção de um controle masculino. ${ }^{4}$ As disparidades entre os sexos são percebidas enquanto questões naturais, de um "determinismo biológico". Inserida na natureza, em algo inacessível à ação humana, a dominação das mulheres pelos homens não só é justificada, como é feita invisível, despercebida. ${ }^{5}$

As mulheres são vistas como os "outros" do sujeito falante e pensante. $\mathrm{O}$ problema das relações entre os sexos em todos os seus aspectos é proveniente não de uma "realidade ontológica denominada 'natural', mas de uma relação de dominação que, embora pareça não poupar nenhuma sociedade e nenhuma época da História, é apresentada como culturalmente construída e, portanto, passível de ser superada". ${ }^{6}$ A mulher é definida relativamente ao homem, não é um ser autônomo. Por ser o "diferente", o feminino só pode usufruir da igualdade na medida em que se assemelhe ao grupo dominante. ${ }^{7}$

Os sexos são associados a noções de "masculinidade" e "feminilidade" construídas socialmente - e a dominação masculina, que marca as relações sociais de sexo, é que vai dizer o que é considerado "normal" ou "natural" para homens e mulheres. A virilidade ou masculinidade é relacionada à força, coragem, violência e aos privilégios da dominação das pessoas que não podem ou não são viris, ou seja, mulheres e crianças. É manifestada também com a sexualidade mas-

4 APFELBAUM, Erika. Dominação. In: HIRATA, Helena; e outras. (org.). Dicionário Crítico do Feminismo. São Paulo: Editora UNESP, 2009. p. 76-80.

5 VARIKAS, Eleni. Igualdade. In:HIRATA, Helena; e outras. (org.). Dicionário Crítico do Feminismo. São Paulo: Editora UNESP, 2009. p. 117.

6 COLLIN, Françoise. Diferença dos sexos (teorias da). In: HIRATA, Helena; e outras. (org.). Dicionário Crítico do Feminismo. São Paulo: Editora UNESP, 2009. p. 59-61.

7 VARIKAS, Eleni. Igualdade. In: HIRATA, Helena; e outras. (org.). Dicionário Crítico do Feminismo. São Paulo: Editora UNESP, 2009. p. 117-118. 
culina. ${ }^{8}$ A feminilidade, por outro lado, manifesta-se pelo oposto: submissão, fragilidade, delicadeza e sexualidade dominada. Às mulheres é atribuída apenas a vida doméstica, aos homens a pública.

A construção feminista, já a partir do século XX, opõe-se a ideia de que a natureza tem o controle sobre o "destino" da mulher. Em O Segundo Sexo, Beauvoir afirma simultaneamente a necessidade de acesso ao universal, que pertence aos homens, e a realidade de diferença entre os sexos, que não seria justificativa para a hierarquia social e política estabelecida entre homens e mulheres. Afirma, ainda, a construção histórica do conceito de mulher, que, para além de meros elementos biológicos que diferenciam o "macho" da "fêmea", o "ser mulher" é algo imposto e formado socialmente, imposto à mulher. A diferenciação que define o masculino e o difere do feminino ocorre na infância e passa a noção de que o feminino é inferior. ${ }^{9}$ A construção social da ideia de homem e mulher é chamada pelo feminismo de "gênero", diferenciado da noção de sexo biológico. ${ }^{10}$

A dissimetria nas relações entre homens e mulheres, especialmente no que concerne ao espaço público, é um produto do patriarcado, o regime da dominação-exploração das mulheres pelos homens, baseado no controle e no medo. ${ }^{11}$ É, assim, a composição da sociedade em que homens

8 MOLINIER, Pascale; WELZER-LANG, Daniel.Feminilidade, masculinidade, virilidade. In: HIRATA, Helena; e outras. (org.). Dicionário Crítico do Feminismo. São Paulo: Editora UNESP, 2009. p. 101-106.

9 COLLIN, Françoise. Diferença dos sexos (teorias da). In: HIRATA, Helena; e outras. (org.). Dicionário Crítico do Feminismo. São Paulo: Editora UNESP, 2009. p. 65-66; BEAUVOIR, Simone. O Segundo Sexo. I. Fatos e Mitos. Tradução de Sérgio Milliet. 4. ed. São Paulo: Difusão Européia do Livro, 1970. p. 9.

10 MATHIEU, Nicole-Claude. Sexo e gênero. In: HIRATA, Helena; e outras. (org.). Dicionário Crítico do Feminismo. São Paulo: Editora UNESP, 2009. p. 223.

11 SAFFIOTTI, Heleieth. Gênero, patriarcado e violência. 2. ed. São Paulo: 
dominam e mulheres são submetidas. Elas foram afastadas dos processos decisórios, inferiorizadas na distribuição de papéis sociais, tornadas inaptas às funções públicas e restritas ao universo doméstico. ${ }^{12} \mathrm{O}$ patriarcado impõe o mito da maternidade, sem o qual as mulheres poderiam questionar a obrigação de ter filhos e, com isso, mudar o sentido de suas vidas - sair da lógica meramente maternal. As mulheres são vistas enquanto "reprodutoras de herdeiros" ${ }^{13} \mathrm{O}$ feminino é confundido com o materno e restrito ao corpo. ${ }^{14}$

Os homens nunca abdicaram do privilégio. A mulher foi condenada a desempenhar o papel do Outro e, desse modo, estaria igualmente condenada a possuir uma força precária, sem nunca escolher seu destino. Sendo o Outro, ela é a passividade em face à atividade, a desordem que resiste à ordem; ela é o mal. ${ }^{15}$

O feminismo observa que as mulheres não nascem livres e iguais, e que a diferença entre os sexos é política: "é a diferença entre liberdade e sujeição", aduz Pateman. A autora trabalha com o contratualismo, estabelecendo que a relação entre homens e mulheres firma um contrato sexual, proveniente do contrato original, que subordina as mulheres, as reclui ao ambiente doméstico e tira-lhes direitos e liberdades - inclusive liberdade quanto ao próprio corpo, pois dá aos homens o livre acesso e domínio dos corpos

Expressão Popular / Fundação Perseu Abramo, 2015. p. 47 e p. 129.

12 RIOT-SARCEY, Michèle. Poder(es). In: HIRATA, Helena; e outras. (org.). Dicionário Crítico do Feminismo. São Paulo: Editora UNESP, 2009. p. 183-186.

13 SAFFIOTTI, Heleieth. Gênero, patriarcado e violência. 2. ed. São Paulo: Expressão Popular / Fundação Perseu Abramo, 2015. p. 112-113.

14 CHAUÍ, Marilena. Participando do Debate sobre Mulher e Violência. In: CHAUÍ, Marilena; PAOLI, Maria Celia. (Org.). Perspectivas Antropológicas da Mulher 4. Rio de Janeiro: Zahar, 1985. p. 38-39 e p. 45.

15 BEAUVOIR, Simone. O Segundo Sexo. I. Fatos e Mitos. Tradução de Sérgio Milliet. 4. ed. São Paulo: Difusão Européia do Livro, 1970. p. 97 e p. 101. 
femininos. O contrato sexual é desigual e assim serve aos interesses dos homens.

\section{Representação política e o feminismo}

Se a história das mulheres é feita para o mundo privado, o ambiente em que se pode examinar em grande medida essa situação é o político. Com efeito, a representação exercida no Parlamento, ou no Poder Executivo, ficou incumbida desde sempre aos homens, proprietários, brancos e livres. Revisar o surgimento da representação é importante, porque revela a exclusão, desde a origem, da mulher no universo político, bem como sua luta paulatina para se inserir nesse meio.

Repraesentare não se origina do mundo político. Do latim, ele significa literalmente "colocar a frente", isto é, fazer a presença de alguém ou trazer alguma coisa à presença. Um fazer ou trazer que pode ser tanto uma ideia, quanto um objeto, ou uma pessoa. Ele alude, ainda, às ciências, à dramaturgia, às artes. É um vocábulo, cujo mapa semântico revela a sua complexidade e abstração. ${ }^{16}$

Hanna Pitkin explica que para compreender o conceito de representação no campo da política é preciso primeiramente examinar o desenvolvimento histórico das instituições. Retorna-se, assim, ao momento da convocação de cavaleiros e burgueses (ingleses) para reunirem-se no parlamento com o rei e os lordes, que se iniciou como "uma questão de conveniência administrativa e política para o rei" ${ }^{17}$ Por meio destas reuniões que paulatinamente foi se aceitando que o membro poderia promover o interesse da comunidade. Os

16 PITKIN, H. F. El concepto de representacion. Madrid: Centro de Estúdios Constitucionales, 1985.

17 PITKIN, H. F. Representação: palavras, instituições, ideias. Lua Nova, São Paulo, n. 67, p. 15-47, 2006, p.26. 
cavaleiros e burgueses eram visualizados como servidores, delegados ou procuradores da comunidade, mas não eram chamados de representantes. Na medida em que passam a atuar como um corpo unificado esses membros começaram a se ver como aqueles que vinham pela comunidade do local. Posteriormente, emergiu a ideia de que cada membro do parlamento atua para a população como um todo. ${ }^{18}$

Teoricamente, foi o inglês Thomas Hobbes quem, muito embora desenhe a representação de forma subjacente ao absolutismo, desenvolveu uma teoria que se constitui na base da concepção política moderna de representação. Distanciando-se da mera concepção de representante como mandatário ou procurador, frequente no período medieval, para Hobbes o soberano é constituído por meio da autorização do povo. ${ }^{19}$ Sai-se, portanto, da cópia à criação e do reflexo à invenção, evocando o reconhecimento entre governante $\mathrm{e}$ governado. ${ }^{20}$

O autor distingue duas formas de pessoas, as naturais, cujas palavras são suas, e as artificiais "consideradas como representando as palavras e ações de um outro" ${ }^{21}$ Por meio da representação se cria um corpo político antes inexistente, que possui poderes ilimitados de ação. Evidentemente que esta última faceta da representação hobbesiana foi revista, mas a estrutura em si da representação política foi a partir daí desenhada.

18 PITKIN, H. F. Representação: palavras, instituições, ideias. Lua Nova, São Paulo, n. 67, p. 15-47, 2006, p.26.

19 HOBBES, T. O leviatã. São Paulo: Abril Cultural, 1974. (Coleção Os Pensadores).

20 HOLLANDA, Cristina Buarque de. Modos de representação política. Belo Horizonte: Editora UFMG; Rio de Janeiro: IUPERJ, 2009.

21 HOBBES, T. O leviatã. São Paulo: Abril Cultural, 1974. (Coleção Os Pensadores), p.121. 
No decorrer do século XVI e seguintes, a Inglaterra reestrutura as prerrogativas da monarquia, sendo que com a revolução gloriosa, deu-se início a forma de governo parlamentar. ${ }^{22}$ Tanto a revolução inglesa quanto a francesa exigiram a reformulação dos moldes de governo, por meio de um formato distinto daquele do ancien regime, o qual não supria o contexto econômico, político e social do momento.

$\mathrm{O}$ ambiente inglês vive a efervescência dos ideais de liberdade e propriedade, as quais emergem como direitos fundamentais do indivíduo em um eixo político-social, tendo o consenso como "fundamento de legitimidade do governo, o voto como instrumento de verificação e de expressão do próprio consenso e a representação como ponte entre a sociedade e o governo". ${ }^{23}$

É o caso de John Locke, que associava a igualdade à propriedade de bens externos, relacionando-os aos méritos de quem o titulava: "todos os seres humanos são iguais, mas alguns são mais completamente humanos do que outro". ${ }^{24}$ $\mathrm{O}$ "todos" de Locke, contudo, não incluía a totalidade de indivíduos de uma sociedade. Era a propriedade que definia o sujeito. Um sujeito no gênero, evidentemente, exclusivamente masculino. ${ }^{25}$

Do outro lado do Atlântico, os federalistas estadunidenses enxergavam a representação como a grande invenção da modernidade, uma vez que permitia o exercício de um poder do povo e evita os perigos das facções, proporcionan-

22 COSTA, Pietro. Poucos, muitos, todos: lições da história da democracia. Curitiba: Editora UFPR, 2012. p.85.

23 COSTA, Pietro. Poucos, muitos, todos: lições da história da democracia. Curitiba: Editora UFPR, 2012.p.86

24 LOCKE, John.Segundo tratado sobre o governo. Clube do livro liberal, 2002.

25 COSTA, Pietro. Poucos, muitos, todos: lições da história da democracia. Curitiba: Editora UFPR, 2012.p.173. 
do uma distância necessária entre eleitores e eleitos. Pietro Costa observa que a despeito de a representação remeter à igualdade, ela finda por acarretar em distinções marcantes "abrindo um fosso dificilmente transponível entre eleitores e eleitos", marcando a narrativa dos séculos seguintes. A representação confere aos representados a soberania de eleger seus representantes, cujo poder se esgota nesta eleição. ${ }^{26}$

Contudo, as vicissitudes do século XIX fazem com que se reanalise o modelo representativo republicano já adotado. Isso porque a escolha dos experts para os cargos políticos se encontra insuficiente diante da iminência da insurgência de uma "multidão indiscriminada". O voto e a propriedade são a solução perfeita a esses escopos, fazendo aparecer as elites sociais e impedindo o ingresso das massas no poder. A propriedade, atrelada à liberdade, torna-se imprescindível para o exercício dos direitos políticos.

Havia, por suposto, uma corrente conservadora que via no sufrágio universal um cavalo de Tróia para a representação, uma vez que ela colocaria em risco as propriedades da minoria. ${ }^{27} \operatorname{Logo}$, a vertente conservadora que se opunha a um princípio democrático impunha essa oposição por meio de um sufrágio censitário e uma concepção de representação que reproduziria a já conhecida inserção de experts na política. ${ }^{28}$

E é nesse contexto que se começa a observar a luta pelas mulheres não só na política, mas no feminismo enquanto tal. Historicamente, as demandas feministas se iniciaram na

26 COSTA, Pietro. Poucos, muitos, todos: lições da história da democracia. Curitiba: Editora UFPR, 2012.p.86

27 COSTA, Pietro. Poucos, muitos, todos: lições da história da democracia. Curitiba: Editora UFPR, 2012.p.86

28 PISARELLO, Gerardo. Um largo termidor. Historia e critica do constitucionalismo antidemocrático. Quito: Corte Constitucional para el partido de transicion, 2012. p.16. 
luta pelo direito ao voto ${ }^{29}$, ingressaram em uma luta contra o patriarcado para se atingir a igualdade entre homens e mulheres, até chegar à reivindicação da autonomia da sexualidade feminina. O feminismo aglutina em torno de si uma grande diversidade de vozes e demandas, e forma-se assim "como o grande eco que modifica as formas de ser dos comportamentos humanos em sociedade, refutando falsas posturas morais, assumidas como universais quando apenas manifestam o latente desejo de permanência viril no poder" ${ }^{30}$

O que ocorre é um debate ampliado, com reivindicações reais de conquistas significativas, envolvendo igualdade salarial, acesso profissional, direitos civis e direitos relacionados à saúde, família, creches, sexualidade, representação política e voz autônoma. São conjuntos de mulheres que se organizam na defesa de seus interesses e

29 A luta pelo direito ao voto teve como expoentes mulheres de classes sociais mais altas, com algum grau de estudo; não foi um movimento unânime ou que englobou toda a coletividade das mulheres. Eram mulheres da elite, que queriam emancipação econômica, intelectual e participação política. $\mathrm{O}$ desejo era pelo cumprimento das promessas do Estado que se dizia liberal, com o fim de privilégios oligárquicos na predominância exclusivamente masculina. A luta contra o patriarcado, por sua vez, passou a envolver um maior número de mulheres trabalhadoras, operárias, que figuravam como "repositoras" de mão de obra masculina e reprodutoras de mão de obra, a partir da maternidade, sem direitos que lhes garantissem iguais condições. Essas mulheres, dentro do movimento operário, eram vistas como "companheiras", mas não eram protagonistas. Passado o momento de luta por um direito considerado "elitista", que foi o direito ao voto (tendo em vista que foi protagonizado por mulheres ricas e instruídas e que não significava uma mudança na estrutura de dominação e exploração das mulheres como um todo), as operárias ingressam no movimento feminista a partir de então e passam a compô-lo de maneira plena. [PAOLI, Maria Celia. Mulheres: lugar, imagem, movimento. In: CHAUÍ, Marilena; PAOLI, Maria Celia. (Org.). Perspectivas Antropológicas da Mulher 4. Rio de Janeiro: Zahar, 1985. p. 63-99.].

30 SANTOS, Magda Guadalupe dos. O feminismo na história: suas ondas e desafios epistemológicos. In: BORGES, Maria de Lourdes; TIBURI, Márcia. (Org.). Filosofia: machismos e feminismos. Florianópolis: Ed. da UFSC, 2014. p. 129-130. 
levantaram a questão da posição da mulher na sociedade e na política, tornando-se assim também sujeitos políticos. "A interrogação apaixonada que vai desde a sexualidade até o trabalho feminino, passando pela maternidade, padrões dominantes de reprodução, responsabilidades familiares, espaço doméstico, relações entre os dois sexos - relevou-se capaz de mexer a fundo com noções amortecidas sobre a mulher e seu mundo, e também com noções cristalizadas de mobilização política." ${ }^{31}$ Os grupos que aglutinam a luta feministas são diversos, com mulheres das mais variadas profissões, procedências, histórias distintas, questionando simultaneamente suas vidas e sua posição subalterna. Esse reconhecimento de uma identidade e a elaboração de seus temas e reivindicações por parte das mulheres, nutre a proposta de uma política feminista questionadora da teia de opressões e discriminações da sociedade.

O feminismo se traduz enquanto a "teoria política que se baseia na análise das relações entre os sexos, bem como na prática da luta de libertação das mulheres", dada a constatação de que os homens dominam e se sobrepõem às mulheres. Alice Schwarzer aduz que "as mulheres são muito mais do que desfavorecidas. As mulheres são párias numa sociedade masculina. Mesmo que sua situação assuma distintas formas, de acordo com a classe social (de seus pais e maridos), com a raça, a idade, a situação familiar e a cor da pele, todas elas não escapam ao estigma mais marcante que pode haver na sociedade de hoje: ser mulher. ${ }^{32}$ As lutas feministas, portanto,

31 PAOLI, Maria Celia. Mulheres: lugar, imagem, movimento. In: CHAUÍ, Marilena; PAOLI, Maria Celia. (Org.). Perspectivas Antropológicas da Mulher 4. Rio de Janeiro: Zahar, 1985. p. 66-68.

32 SCHWARZER, Alice. As feministas são piratas.In:SOLIZ, Neusa. (Org.) A mulher no século XXI: um estudo de caso, a Alemanha. Tradução de Neusa Soliz. Rio de Janeiro: Espaço e Tempo; São Paulo: Instituto Goethe, 1988. p. 136-138. 
"partem do reconhecimento das mulheres como específica e sistematicamente oprimidas, na certeza de que as relações entre homens e mulheres não estão inscritas na natureza, e que existe a possibilidade política de sua transformação."33

Ainda que sejam de muita importância as reivindicações feministas junto ao Estado, as mudanças dependem de uma transformação radical das relações entre homens e mulheres, de modo a quebrar com "a desigualdade disciplinada de mundos estanques, tarefeiros e repressores", em que todas as interações sociais representam opressões e também em que a violência emerge em diversas maneiras ${ }^{34}$ - mesmo porque o Estado é uma instituição masculina que reflete o ponto de vista dos homens, apoiados em normas masculinas consagradas como universais. ${ }^{35}$ Assim, a atuação do movimento engloba, simultaneamente, a sociedade, na perspectiva de mudanças nas relações entre homens e mulheres, e o Estado, buscando alteraçõesnas leis que oprimem e punem mulheres.

Foi somente após o fim da segunda guerra mundial se rediscutiu as condições estruturais de democracia. ${ }^{36}$ Começam então a surgir questionamentos sobre o governo representativo, que, ancorados em discursos pós-democráticos invocam condicionantes como "a perda de centralidade dos partidos

33 FOUGEYROLLAS-SCHWEBEL, Dominique. Movimentos feministas. In: HIRATA, Helena; e outras. (org.). Dicionário Crítico do Feminismo. São Paulo: Editora UNESP, 2009. p. 144-145.

34 PAOLI, Maria Celia. Mulheres: lugar, imagem, movimento. In: CHAUÍ, Marilena; PAOLI, Maria Celia. (Org.). Perspectivas Antropológicas da Mulher 4. Rio de Janeiro: Zahar, 1985. p. 74.

35 HEINEN, Jacqueline. Políticas sociais e familiares. In: HIRATA, Helena; e outras. (org.). Dicionário Crítico do Feminismo. São Paulo: Editora UNESP, 2009. p. 190.

36 SANTOS, Boaventura de Souza e AVRITZER, Leonardo. Introdução: para ampliar o cânone democrático. In: Democratizar a democracia: os caminhos da democracia participativa. Rio de Janeiro: Civilização Brasileira, 2002. 
de massas, mudanças de hábitos políticos dos eleitores, erosão das grandes categorias sociais atreladas ao mundo do trabalho, a crescente expansão das funções de comunicação política desempenhadas pela mídia e possibilidade de voto das mulheres". ${ }^{37}$

Com efeito, só com o alcance da cidadania efetiva a todos os homens e mulheres que a democracia liberal se perfez em seu molde contemporâneo: um plexo de regras e instituições que admite o envolvimento de todos os cidadãos na escolha dos representantes que tomarão decisões que afetarão a vida de toda uma comunidade. ${ }^{38} \mathrm{E}$ é nesse contexto que se pode examinar o crescimento de vertentes que buscam resgatar a concepção tradicional de democracia.

Para Carole Pateman, a defesa da democracia participativa tem sua origem em Rousseau, para quem soberania não só provémdo povo, mas é com este que deve permanecer. Como consequência, não há, consoante essa concepção, espaço para a representação política, pois é incumbência de todos os cidadãos o poder de legislar. Ao príncipe, ao passo, cabe apenas executar a vontade geral. Pateman critica a perda desses ideais, especialmente no que concerne às igualdades, uma vez que de acordo com o pensamento elitista, essa se reduz a uma igualdade perante a lei, para escolha do representante. ${ }^{39}$

A participação popular é mecanismo indispensável para a consolidação da democracia. É fundamental que se integre a sociedade ao contexto sócio-político, com consequ-

37 GURZA LAVALLE, Adrian, Após a participação: nota introdutória. Lua Nova, São Paulo, 84: 13-23, 2011.

38 HELD, David. La democracia y el orden global. Del estado moderno AL gobiernocosmopolita.Barcelona: Paidos, 1997,p.30.

39 PATEMAN, Carole. Participação e teoria democrática. Tradução Luiz Paulo Rouante. Rio de Janeiro: Paz e Terra, 1992. 
ências diretas na incorporação de práticas que impulsionem o controle social. ${ }^{40}$

Assim, a democracia participativa emerge defendendo o envolvimento do cidadão enquanto tal nas instituições sociais e políticas. A representação, de outro modo, não deixa de estar presente, mas não se resume na única modalidade de desenho democrático institucional. Nessa perspectiva, a democratização estatal representa justamente a utilização desses instrumentos participativos. O processo decisório, seja na polis, seja no demos, é democrático. ${ }^{41}$ Esse debate saiu do ambiente acadêmico e ingressou nos governos, sendo que o fenômeno participativo é hoje uma tendência mundial.

\section{Do processo de instrumentalização da par- ticipação social no Brasil}

A democracia que surgiu na década de 1970 no sul da Europa chega a América Latina nos anos 1980 inserindo a discussão sobre a relação entre procedimento e participação social, como efetivadores da democracia. Essa nova gramática modificou as relações das minorias e do patriarcado com os bens públicos o que ensejou um experimentalismo na esfera pública, transformando o Estado em um movimento social. ${ }^{42}$ Para que se tenha uma participação efetiva dos cidadãos na tomada de decisões, "o Estado deve prever mecanismos e

40 SOUZA, Patrícia Verônica Nunes Carvalho Sobral de; CARDOSO, Henrique Ribeiro. Participação popular e controle social: uma análise dos conselhos públicos à luz da teoria habermasiana. Revista Brasileira de Estudos Políticos, Belo Horizonte, n. 116, pp. 309-349, jan./jun. 2018, p. 318.

41 LIMA JUNIOR, Olavo Brasil de. Instituições Políticas Democráticas: o segredo da legitimidade. Rio de Janeiro: Jorge Zahar editor, 1997

42 SANTOS, Boaventura de Souza e AVRITZER, Leonardo. Introdução: para ampliar o cânone democrático. In: Democratizar a democracia: os caminhos da democracia participativa. Rio de Janeiro: Civilização Brasileira, 2002. 
regras estáveis que propiciem uma prática permanente do debate na sociedade e tornem possíveis acordos coletivos entre os cidadãos". ${ }^{43}$

Pensar a democracia participativa é pensar no papel que os sujeitos desempenham socialmente. "O cidadão não pode reduzir-se ao eleitor, mas deve ser também um indivíduo participante e controlador da atividade estatal. A democracia participativa implica o exercício direto e pessoal da cidadania nos atos de governo." ${ }^{44}$

Embora a década de 80 tenha enfrentado duras perdas econômicas, o que fez com que fosse batizado de "a década perdida", foram nesses anos que se viu um crescimento da organização popular e experiências de participação germinado. ${ }^{45} \mathrm{O}$ cenário subsequente foi o desenvolvimento de um cenário político que permitiu a realização de uma Assembleia Constituinte, que foi composta também pela participação da sociedade. Esse processo, "maculado pela origem da Assembleia Nacional Constituinte e por seu funcionamento legitimado pela participação popular" foi "capaz de estabelecer, se não um conceito concreto de democracia, um projeto democrático que traz para vida real fins democráticos" ${ }^{46}$

43 BONAT, Debora. PEIXOTO, Fabiano Hartmann. O incremento da cidadania através do reforço da participação popular e a crescente judicialização da política. Revista Brasileira de Estudos Políticos. Belo Horizonte, n. 112, pp. 109-146, jan./jun. 2016, p. 134.

44 PEDRA, Adriano Sant'Ana. Participação popular no poder local: o papel do cidadão no aprimoramento das decisões do Executivo e do Legislativo municipal. Revista Brasileira de Estudos Políticos, Belo Horizonte, n. 100, p. 29-56, jan./jun. 2010, p. 30.

45 GURZA LAVALLE, Adrian. Após a participação: nota introdutória. Lua Nova, São Paulo, 84: 13-23, 2011, p.13.

46 SALGADO, Eneida Desiree. Constituição e Democracia:Tijolo por tijolo em um desenho (quase) lógico: Vinte anos de construção do projeto democrático brasileiro. Belo Horizonte: Fórum, 2007. 280. 
O marco distintivo dessa luta é, indubitavelmente, a promulgação da Constituição em 1988. Como meio de garantir os projetos propostos pelos movimentos sociais, estabeleceu-se não só um Estado Democrático de Direito, como um Estado promotor de políticas públicas. Desde a década de 90, interfaces socioestatais passaram a ser implementadas, instrumentalizadas, readaptadas, repaginadas e utilizadas promovendo dinâmicas distintas entre Estado e sociedade. Assistiu-se, ainda, à implantação de diversos requisitos institucionais para prosseguir com a proposta de descentralização política e formação de instâncias colegiadas para corroborar na formulação e controle de políticas públicas.

Assim, se entre as décadas de 1960 e 1980 a participação correspondia à contraposição ao regime militar, atualmente ela é o reclamo de autodeterminação efetiva e parte da linguagem jurídica do Estado, alcançando ambientes inesperados, tornando-se uma feição institucional. ${ }^{47} \mathrm{O}$ povo é o detentor da soberania e, nesse sentido, ele "é quem deve exercê-lo seja de forma delegada através de seus representantes, assegurada a lisura do pleito a fim de que seja conferida legitimidade aos eleitos, ou então, sem representação, exercido diretamente pelo cidadão." 48

Embora mais modesta nos âmbitos legislativo e judiciário, a participação já é premissa de primeira ordem em todas as esferas de poder. Estudos revelam que, se em 2002 não haviam instrumentos participativos na Câmara dos Deputados e no Senado Federal, em 2010 o cenário já é distinto,

47 GURZA LAVALLE, Adrian.Após a participação: nota introdutória.Lua Nova, São Paulo, 84: 13-23, 2011.

48 BONAT, Debora. PEIXOTO, Fabiano Hartmann. O incremento da cidadania através do reforço da participação popular e a crescente judicialização da política. Revista Brasileira de Estudos Políticos. Belo Horizonte, n. 112, pp. 109-146, jan./jun. 2016, p. 135. 
com a inserção de instrumentos participativos nas atividades do Parlamento. O Judiciário, por sua vez, foi paulatinamente implementando em seus programas tais mecanismos. ${ }^{49}$

No plano executivo, surgiram diversos mecanismos participativos, tais como: comitês, ombudsman, leis de transparência, instituições eleitorais de caráter civil, observatórios cidadãos, comissões de vigilância, Conselhos, Comissões, Conferências, entre outros. ${ }^{50}$ Algumas dessas inovações alcançaram mundial notoriedade: os Conselhos Gestores de Políticas Públicas, as experiências de Orçamento Participativo (OP) e as Conferências Nacionais no Brasil. Esse pioneirismo foi importado e implantado em diversos países, colocando o Brasil como local de ponta da instrumentalização de experiências participativas. ${ }^{51}$

Momento relevante na guinada participativa foi o início da gestão do Presidente Lula em 2003. A literatura aponta para um verdadeiro salto nos projetos de implementações de instrumentos participativos em razão do direcionamento dado pelo Partido dos Trabalhadores para a ampliação das interfaces participativas. ${ }^{52}$ Além disso, as políticas governamentais apoiadas em experiências participativas também

49 PIRES,R.R.C.;VAZ,A.C.N. Para além da participação: interfaces socioestatais no governo federal. Lua Nova, São Paulo, n. 93, p. 61-91, 2014.

50 GURZA LAVALLE, A.; ARAÚJO, C. Ofuturo da representação: nota introdutória.Lua Nova, São Paulo, n. 67, p. 9-13, 2006.

51 GURZA LAVALLE, A.; HOUTZAGER, P. P.; CASTELLO, G. A construção política das sociedades civis. In: GURZA LAVALLE, A. (Org.). O horizonte da política. Questões emergentes e agenda de pesquisa. São Paulo: Unesp, 2012.

52 Sobre o tema: SANTOS, B. de S.; AVRITZER, L. Introdução: Para ampliar o cânone democrático. In: SANTOS, B. de S. Democratizar a democracia: os caminhos da democracia participativa. Rio de Janeiro: Civilização Brasileira, 2002; POGREBINSCHI, T.; SANTOS, F. Participação como representação: O impacto das Conferências Nacionais de Políticas Públicas no Congresso Nacional. Revista de Ciências Sociais, Rio de Janeiro, v. 54, n. 3, p. 259-305, 2011. 
cresceram. ${ }^{53}$ Houve um incremento no número de programas que deram abertura a instrumentos participativos no âmbito federal, de $81 \%$, em 2002, para 92,1\%, em 2010, além da diversificação de órgãos que passaram a implantar esses mecanismos, uma vez que, em 2002, 60,4\% dos órgãos tinham programas desse tipo ao passo que, em 2010, esse percentual chegou a $89,3 \%$ dos órgãos federais. ${ }^{54}$

De todas essas inovações democráticas, as que mais tem sido objeto de estudo são as Conferências Nacionais e os Conselhos Gestores de Políticas Públicas. De acordo com o art. 2. ${ }^{\circ}$ IV , da Lei n. ${ }^{\circ}$ 8243/2014, Lei da PNPS, a Conferência Nacional é uma instância periódica de debate, de formulação e de avaliação sobre temas pontuais que sejam de interesse público, que são realizados por meio da participação de representantes do governo e da sociedade civil, contemplando etapas estaduais, distrital, municipais ou regionais, com o escopo de apresentar diretrizes sobre o tema.

$\mathrm{O}$ art. 12 impõe as diretrizes como baliza para as conferências, dentre as quais se destaca a divulgação ampla e prévia do documento convocatório, especificando seus objetivos e etapas. As Conferências Nacionais foram criadas no início dos anos 1940, quando o governo Vargas convocou a Conferência Nacional de Saúde. Contudo, foi somente a partir de 1988 que as formas de participação da sociedade civil previstas pela Constituição nas áreas de saúde e assistência social institucionalizaram as Conferências Nacionais.

53 COELHO, V. S. P.; FAVRETO, A. Conexões entre participação, democracia e desenvolvimento: investigação dos impactos políticos e distributivos. In: GURZA LAVALLE, A. (Org.). O horizonte da política: Questões emergentes e agendas de pesquisa. Questões emergentes e agenda de pesquisa. São Paulo: Unesp, 2012.

54 PIRES, R. R. C.; VAZ, A. C. N. Para além da participação: interfaces socioestatais no governo federal. Lua Nova, São Paulo, n. 93, p. 61-91, 2014. 
Seguidamente, outro relevante impulso às Conferências Nacionais se deu após 2003, com o início da gestão de Luiz Inácio Lula da Silva. ${ }^{55}$

Segundo a página do Partido dos Trabalhadores, de 1941 a 2014 foram realizadas 144 conferências, sendo que 103 ocorreram entre 2003 e 2014, abrangendo mais de 40 áreas setoriais nas três esferas estatais. ${ }^{56}$ Segundo dados da página "Brasil da Mudança", entre 2003 e 2014 mais de 9 milhões de cidadãos participaram de 98 Conferências Nacionais sobre temas como educação, participação, saúde, mulheres, comunicação, direitos da população LGBT. ${ }^{57}$

Pesquisa realizada pelos pesquisadores Fabiano Santos e ThamyPogrebinschi do Instituto Universitário de Pesquisas do Rio de Janeiro (IUPERJ) revela que a característica principal das Conferências é o seu impacto sobre o Poder Legislativo: "As conferências nacionais impulsionam a atividade legislativa do Congresso Nacional, fortalecendo, assim, através de uma prática participativa e deliberativa, a democracia representativa no Brasil" ${ }^{58}$ Atualmente, as Conferências Nacionais são conhecidas como a principal política participativa do governo federal. Todavia, os re-

55 POGREBINSCHI, T.; SANTOS, F. Participação como representação: O impacto das Conferências Nacionais de Políticas Públicas no Congresso Nacional. Revista de Ciências Sociais, Rio de Janeiro, v. 54, n. 3, p. 259-305, 2011.

56 MENDONÇA, M. P. Participação social: nenhum passo atrás! Disponível em: http://www.ipea.gov.br/participacao/noticiasmidia/participacaoinstitucional/1185-participacao-social-nenhum-passo-atras. Acesso em: 15.01.2018.

57 MUDANÇA, O Brasil da. Disponível em: <http://www.brasildamudanca. com.br/participacao-e-transparencia/participacao-e-transparencia>. Acesso em: 15.01.2018.

58 POGREBINSCHI, T.; SANTOS, F. Participação como representação: O impacto das Conferências Nacionais de Políticas Públicas no Congresso Nacional. Revista de Ciências Sociais, Rio de Janeiro, v. 54, n. 3, p. 259-305, 2011. 
sultados apontam para uma maior necessidade de acesso à informação deste mecanismo. ${ }^{59}$

Outra relevante interface socioestatal são os Conselhos de Políticas Públicas, que têm sua definição no art. 2 . $^{\circ}$ da lei da PNPS, como uma instância colegiada temática permanente, instituída por ato normativo, de diálogo entre a sociedade civil e o governo para promover a participação no processo decisório e na gestão de políticas públicas.

Os Conselhos de Políticas Públicas buscam ser um mecanismo de influência sobre a Administração. Justificam-se como ferramentas de controle público, pretendendo aumentar a participação dos cidadãos nos processos decisórios. ${ }^{60}$ Os alcances dos Conselhos variam de setor a setor, mas em alguns casos o funcionamento deles se integra a operação regular de uma política setorial. Assim como outras interfaces socioestatais, os conselhos exercem controle interno estatal sobre políticas públicas.

Alguns exemplos de conselhos nacionais já existentes são os dos Direitos da Pessoa Humana, o de Combate à Discriminação, o dos Direitos da Criança e do Adolescente e dos Direitos da Pessoa com Deficiência. Segundo dados do governo federal, existem mais de 35 Conselhos Federais no país. ${ }^{61}$ Atualmente existem aproximadamente 30.000 (trinta mil) Conselhos ${ }^{62}$ distribuídos em 97,6 \% dos municípios.

59 AVRITZER, L. Conferências nacionais: Ampliando e redefinindo os padrões de participação social no Brasil. IPEA: Instituto de Pesquisa Econômica Aplicada, 2012.

60 LOPES, José Reinaldo de Lima. Os Conselhos de Participação popular. A validade jurídica de suas decisões. Disponível em: http://www.revistas. usp.br/rdisan/article/viewFile/13073/14875. Acesso em: 15.01.2018.

61 BRASIL. Arena da Participação Social. Disponível em: http://www. secretariageral.gov.br/participacao-social/politica. Acesso em: 15.01.2018.

62 GURZA LAVALLE, Adrian; ISUNZA, Ernesto. Representación y participación en la crítica democrática.Desacatos (CIESAS), v. 49, p. 10-27, 2015, p.17. 
Credita-se esse aumento de Conselhos em razão dos repasses intergovernamentais da União aos Municípios pela criação deles. De modo que se afirmar que existem mais Conselheiros exercendo função de representação que vereadores municipais. ${ }^{63}$

Em regra, os Conselhos são previstos na legislação nacional, podendo ou não ter caráter obrigatório e se relacionam às políticas públicas mais estruturadas ou concretizadas em sistemas nacionais. Gohn salienta que os Conselhos têm suas atribuições instituídas por lei e compõem as práticas de planejamento e fiscalização das ações. ${ }^{64}$

Em que pese o $\mathrm{STF}^{65}$ já tenha se manifestado contrariamente à atribuição de competência decisória aos Conselhos que possa implicar um esvaziamento do juízo de conveniência e oportunidade de uma determinada política por agentes estatais, eventual caráter vinculativo das deliberações conselhistas pode ser identificado no ato de criação destes. Por isso, suas decisões podem deter poderes normativos infralegais, sendo que o impeditivo repousa na criação de efeitos concretos. Mas ainda inexiste decisão definitiva do STF sobre uma eventual sobreposição das deliberações dos Conselhos as decisões do Chefe do Poder Executivo.

Nada obstante, ainda que não detenham poder para decidir de fato sobre determinada política pública, nos conselhos é possível vetar determinadas decisões governamentais, as quais podem implicar, por exemplo, na paralisação de obras, em vetos de convênios, na suspensão de repasses de recursos entre outras medidas. ${ }^{66}$ No âmbito dos Conselhos,

63 GURZA LAVALLE, Adrian; ISUNZA, Ernesto. Representación y participación en la crítica democrática. Desacatos (CIESAS), v. 49, p. 10-27, 2015, p.17.

64 GOHN, M. da G. Empoderamento e participação da comunidade em políticas sociais.Saúde e Sociedade, São Paulo, v. 13, n. 2, p. 20-31, maio/ago. 2004.

65 STF, ADI 2416/DF julgada em 2013.

66 ALMEIDA, Carla; TATAGIBA, Luciana. Os conselhos gestores sob o 
em regra a participação dos cidadãos se dá mediante dispositivos legais que determinam a representação por meio de associações, organizações ou ainda entidades sindicais. ${ }^{67}$ Tais interfaces requerem, concomitantemente, a participação e a representação políticas, substanciando uma forma de "representação oficial da sociedade civil" que exige a atenção do Estado. ${ }^{68}$

A literatura das ciências sociais observa que tal modelo é uma expressão da "pluralização da representação política", constituindo-se um tipo de representação formal institucional. ${ }^{69}$ Trata-se de práticas de representação política que compõem a tipologia alternativa ${ }^{70}$ à representação

crivo da política: balanços e perspectivas. Serv. Soc. Soc., São Paulo , n. 109, p. 68-92, Mar. 2012. Disponível em: http://www.scielo.br/scielo. php?script=sci_arttext\&pid=S0101 66282012000100005\&lng=en\&nrm=iso $>$. Acesso em: 15.01.2018. http://dx.doi.org/10.1590/S0101-66282012000100005.

67 LUCHMANN, Lígia Helena Hahn. Associações, participação e representação: combinações e tensões. Lua Nova, São Paulo, n. 84, p. 141-174, 2011.Disponível em: http://www.scielo.br/scielo.php?script=sci_ arttext\&pid=S0102-64452011000300006\&lng=en\&nrm=iso $>$. Acesso em: 15.01.2018 2016. http://dx.doi.org/10.1590/S0102-64452011000300006.

68 ALMEIDA, Carla; TATAGIBA, Luciana. Os conselhos gestores sob o crivo da política: balanços e perspectivas. Serv. Soc. Soc., São Paulo, n. 109, p. 68-92, mar. 2012 . Disponível em http://www.scielo.br/scielo.php?script=sci_ arttext\&pid=S0101-66282012000100005\&lng=pt\&nrm=iso. Acesso em: 15.01.2018. http://dx.doi.org/10.1590/S0101-66282012000100005.

69 GURZA LAVALLE, A.; ARAÚJO, C. Ofuturo da representação: nota introdutória.Lua Nova, São Paulo, n. 67, p. 9-13, 2006.

70 Segundo Luchmann, os exemplos de representação alternativas são variadas, podendo se dar desde experiências coletivas e individuais, passando por formais e informais, podendo, cada um dessas formas combinar entre si. A representação nos Conselhos Gestores se dá de forma coletiva e formal. A formalidade se refere a existência de regras e a coletiva ao caráter não individual da representação. LUCHMANN, Lígia Helena Hahn. Associações, participação e representação: combinações e tensões. Lua Nova, São Paulo , n. 84, p. 141-174, 2011 . Disponível em http://www.scielo.br/scielo. php?script=sci_arttext\&pid=S0102-64452011000300006\&lng=en\&nrm=iso. 
eleitoral ${ }^{71}$, que ocorrem em espaços deliberativos compostos por cidadãos que representam outros cidadãos no espaço de definição de políticas públicas. ${ }^{72} \mathrm{~A}$ literatura ainda aponta que nesses mecanismos existe uma distinção com o local por excelência de representação política no que se refere ao perfil dos participantes, nos quais algumas interfaces são compostas majoritariamente por mulheres.

\section{A representação feminina nos espaços par- ticipativos: exame dos Conselhos gestores}

Desde a Constituinte de 1987, é possível perceber a baixa participação feminina na política brasileira, notadamente no que se refere ao Legislativo. A chamada "Bancada Feminina" contou com apenas vinte e cinco deputadas constituintes ${ }^{73}$; nenhuma senadora foi eleita. O total de deputados foi de 512 entre titulares e suplentes ${ }^{74}$; então o percentual de participação feminina entre os deputados foi de $4,88 \%$. Considerando-se ainda que o total de parlamentares constituintes (512 deputados e 82 senadores, sendo que Roberto

71 URBINATI, o que torna a representação democrática?. Encontro Anual da American Political Science Association (Apsa), Washington (EUA), setembro de 2005.

72 Nesse sentido: LUCHMANN, Lígia Helena Hahn. Associações, participação e representação: combinações e tensões. Lua Nova, São Paulo , n. 84, p. 141-174, 2011. Disponível emhttp://www.scielo.br/scielo.php?script=sci_ arttext\&pid=S0102-64452011000300006\&lng=en\&nrm=iso.

73 Foram eleitas vinte e seis deputadas constituintes, mas Bete Mendes não chegou propor emendas ao projeto constituinte. Ela se licenciou para assumir o cargo de Secretária de Cultura do Estado de São Paulo. A despeito de contar com vinte e seis deputadas na data da posse, a bancada feminina foi composta por vinte e cinco parlamentares.

74 Disponível em: <http://www2.camara.leg.br/atividade-legislativa/ legislacao/Constituicoes_Brasileiras/constituicao-cidada/constituintes/ deputados-constituintes>. Acesso em: 15.01.2018. 
Saturnino, PT/RJ, não atuou em razão de sua eleição para prefeito da cidade do Rio de Janeiro ${ }^{75}$ ) foi de 594, a representação feminina esteve em $4,20 \%$ do total de representantes. ${ }^{76}$

Ainda que alguns direitos e reivindicações feministas tenham sido atendidos na Constituinte, soam como concessões feitas por uma maioria masculina. Não se pode celebrar como uma conquista tão baixa representatividade - ainda que autores, como Marcius de Souza, considerem a eleição das representantes mulheres como um "pleito histórico" a partir do qual "as mulheres se fizeram representar de forma significativa" ${ }^{77}$ Comparando-se com o pleito anterior, que contou com apenas oito deputadas, houve um avanço. A atuação das mulheres eleitas como representantes na Constituinte promoveu alguns avanços, a exemplo da licença maternidade de 120 dias, da igualdade em direitos entre homens e mulheres e da igualdade formal de salários. ${ }^{78}$

Por outro lado, se existe uma indiscutível baixa participação feminina nos espaços tradicionalmente políticos (poderes Legislativo e Executivo), o mesmo não se pode

75 Disponível em: <http://www2.camara.leg.br/atividade-legislativa/ legislacao/Constituic oes_Brasileiras/constituicao-cidada/constituintes/ senadores-constituintes>. Acesso em: 15.01.2018.

76 Informações disponíveis em: <http://www2.camara.leg.br/atividadelegislativa/legislacao/Constituicoes_Brasileiras/constituicao-cidada/ constituintes/parlamentaresconstituint es/copy_of_index.html $>$; <http:// www2.camara.leg.br/atividade-legislativa/legislacao/Constituicoes_ Brasileiras/constituicao-cidada/constituintes>. Acesso em: 15.01.2018.

77 SOUZA, Marcius F. B. de. A Participação das Mulheres na elaboração da Constituição de 1988. In: Constituição de 1988: O Brasil 20 anos depois. Os Alicerces da Redemocratização (Vol. 1). Brasília: Senado Federal, Instituto legislativo brasileiro, 2008. Disponível em: <http://www12.senado.gov.br/ publicacoes/estudos-legislativos/tipos-de-estudos/outras-publicacoes/ vo lume-i-constituicao-de-1988/principios-e-direitos-fundamentais-aparticipacao-das-mulheres-na-elabor acao-da-constituicao-de-1988/view>. Acesso em: 15.01.2018.

78 SOW, Marilene Mendes. A Participação Feminina na Construção de um Parlamento Democrático. E-legis, n. 05, p. 79-94, 2. semestre, 2010. 
dizer dos espaços políticos construídos nos mecanismos participativos. O fenômeno da participação social operou efeitos na equação da lógica da representatividade feminina na política. Efeitos que passam a ser objeto não só de estudo, mas igualmente de compreensão.

No caso das Conferências Nacionais, pesquisa elaborada por Leonardo Avritzer, revelou que a maioria dos participantes é mulher ( $51,2 \%$ dos casos), com escolaridade superior $(26,9 \%)$ ou com ensino médio completo em $20,3 \%$ dos casos. Em algumas áreas de políticas públicas, como saúde e assistência social, a participação é mais presente. Segundo Avritzer, isso ocorre porque essas temáticas possuem movimentos sociais historicamente fortes.

Rosangela Schulz, Dieni Oliveira Rodrigues e Ana Cristina Mendes investigaram os Conselhos Municipais Direitos da Mulher de Pelotas e Santa Cruz do Sul no Rio Grande do Sul. O objetivofoi delimitar o perfil das conselheiras, bem como discutir a legitimidade da representação.O Conselho de Pelotas teve sua fundação resultante da luta de mulheres organizadas na cidade, sobretudo Movimento Contra a Violência à Mulher, que agregou as mulheres da Igreja Católica, Partido dos Trabalhadores, sindicatos de professores e autônomas. Já o de Santa Cruz do Sul também foi criado por mobilização feminina, mas foi desativado pelo Poder Executivo do Município sendo reativado mediante pressão do movimento feminista.

Em ambos os conselhos, a idade é igual ou superior a 46 anos, predomínio de mulheres casadas, e maioria possui filhos. O perfil econômico é de dois a cinco salários mínimos, com altos índices de escolarização. A maioria das conselheiras participam de entidade ou organização social. As autoras concluem que o perfil das mulheres Conselheiras é similar daqueles que passam pelo crivo eleitoral. Indicam, 
ainda, que as conselheiras veem a si mesmas de forma positiva, visualizando os Conselhos como autônomos, mas os membros como um grupo que atua de maneira conjunta. A pesquisa ainda revela que as conselheiras são atuantes na comunidade, cuja atuação não reflete no desenvolvimento de uma carreira política tradicional. Apontam, finalmente, para o vínculo entre sociedade civil e representação às mulheres. ${ }^{79}$

Ligia Helena Luchmann e Julian Borba em estudo sobre a representação política nos Conselhos Gestores de Políticas Públicas, utilizaram como referência empírica o Conselho dos Municípios de Itajaí e Chapecó, em Santa Catarina. Apontamque, em que pese as mulheres sejam sub-representadas no que tange a representação legislativa municipal, há uma incidência de super-representação feminina no que se refere aos Conselhos de Políticas Públicas nessas cidades, sendo que em média $70 \%$ da amostra é composta por mulheres (quando ocupam menos de $50 \%$ na população total). Relatam, ainda, que em todos os Conselhos a participação feminina é majoritária. ${ }^{80}$

Resultado semelhante foi encontrado por Ligia Helena Luchmann e Carla Cecília Rodrigues Almeida no âmbito dos Conselhos Gestores de Saúde, Assistência Social e Criança e Adolescente. As autoras destacam que, no que se refere ao perfil socioeconômico, tratam-se de mulheres, na sua maioria, brancas, casadas, católicas, com alto nível educacional. Narram que o local de intervenção desses Conselhos é o

79 SHCULZ, Rosangela; Dieni Rodrigues; MENDES, Ana Cristina.A atuação feminina nos Conselhos da Mulher: um estudo dos Conselhos de Pelotas e de Santa Cruz do Sul/RS.Revista Debates, Porto Alegre, v.7, n.3, p.149-168, set.-dez. 2013.

80 LÜCHMANN, L. H.; BORBA. A representação política nos Conselhos [T] Gestores de Políticas Públicas. Disponível em: https://www12.senado. leg.br/publicacoes/estudos-legislativos/tipos-de-estudos/textos-paradiscussao/td158. Acesso em: 15.01.2018. 
social, ambiente que tem um histórico de atuação feminina como campo de sua competência.

O estudo de Ligia Helena Luchmann e Julian Borba nos Conselho dos Municípios de Itajaí e Chapecó também aponta para uma maior participação de mulheres nos Conselhos de Assistência Social (80\%), e a menor no Conselho de Saúde (66.7\%). Ainda, enquanto nos Conselhos de Direito da Criança, a participação é de $78,6 \%$ de mulheres, nos Conselhos Municipais do Idoso é de $71.4 \%$. Concluem os autores que "a área de atuação do conselho parece imprimir influência nesse tipo de composição, que tem demonstrado uma importante inserção política feminina nestes espaços de participação institucional" ${ }^{81}$

O Relatório de Pesquisa do IPEA acerca do perfil e atuação dos Conselheiros Nacionais reforça esse entendimento. Também no âmbito nacional, observou-se uma maior participação feminina em Conselhos relativos à áreas sociais, no qual se apresentou uma participação mais igualitária, $41 \%$ a $54 \%$ de mulheres. Nos demais Conselhos, ao seu turno, a participação masculina supera os $70 \%$.Por outro lado, distintamente da predominância feminina nos Conselhos Municipais, apontou-se para uma predominância masculina de $63 \%$ homens, e $37 \%$ mulheres. A pesquisa explica esses resultados "pelo fato de as mulheres, diferentemente dos homens, ainda serem as principais responsáveis pelos cuidados com a família, o que torna a participação local uma função menos difícil de conciliar com suas funções domésticas" ${ }^{82}$

81 LÜCHMANN, L. H.; BORBA. A representação política nos Conselhos [T] Gestores de Políticas Públicas. Disponível em: https://www12.senado.leg.br/ publicacoes/estudos-legislativos/tipos-de-estudos/textos-para-discussao/ td158. Acesso em: 15.01.2018.

82 IPEA. Relatório de Pesquisa de Conselhos Nacionais de Politicas Públicas. Disponível em: http://www.ipea.gov.br/participacao/images/pdfs/ relatoriofinal_perfil_conselhosnacionais.pdf. Acesso em: 15.01.2018. 
Buscando respostas sobre a maior incidência feminina nas interfaces de área social, Ligia Helena Luchmann e Carla Almeida traçam comparativos entre a representação parlamentar e aquela exercida nos Conselhos. Destacam que no pleito eleitoral os candidatos se expõem à sociedade, sujeitando-se ao crivo dos valores morais e culturais dessa sociedade. Tendo em vista que a sociedade ainda atribui ao gênero feminino as responsabilidades privadas, e ao masculino, as públicas, esses têm maiores chances de se saírem vitoriosos no pleito eleitoral. Daí porque, para as autoras, as chances no âmbito eleitoral são mais reduzidas às mulheres.

Assim, enquanto na seara eleitoral se tem um sistema patriarcal de seleção, nos Conselhos a escolha dos representantes se faz por meio de organizações da sociedade civil, sendo que em diversas oportunidades existem fóruns de discussões, bem como eleições por meio da própria comunidade. Nos Conselhos não se está de fronte à indivíduos, como no mundo eleitoral, mas diante de ideias. ${ }^{83} \mathrm{~A}$ forma de escolha dos representantes, destarte, pode influenciar na presença significativa de mulheres. O vínculo entre sociedade civil e representação aparenta ser mais favorável à inclusão feminina ${ }^{84}$

Costa narra a distinção entre essas representações. O autor ressalva que quando se tem representação feminina no legislativo ou executivo, as demandas e políticas a serem instituídas são distintas, sendo dever da mulher cuidar das crianças e idosos. Há, desse modo, uma divisão sexual do

83 SHCULZ, Rosangela; Dieni Rodrigues; MENDES, Ana Cristina.A atuação feminina nos Conselhos da Mulher: um estudo dos Conselhos de Pelotas e de Santa Cruz do Sul/RS.Revista Debates, Porto Alegre, v.7, n.3, p.149-168, set.-dez. 2013.

84 MANN, L. H. H.; ALMEIDA, C. C. R. A representação política das mulheres nos Conselhos Gestores de Políticas Públicas. Revista Katálysis, v. 13, n. 1, p. 86 
trabalho. Segundo Costa, ainda quando alçada a postos de tomada de decisão "quase que intuitivamente, a mulher encaminha demandas relacionadas com este universo." 85 Assim como o homem tem o papel de produtivo, a mulher detém o reprodutivo, a mulher está para o privado e o homem para o público. Luchmann e Almeida salientam que essas constatações são corroboradas com as pesquisas, as quais revelam a existência de correlação entre setor temática e gênero, o que vem a indicar que determinadas políticas públicas de áreas sociais exercem maior mobilização feminina em detrimento de outras. Suscitam que a correlação entre a área e gênero pode ter relação a concepção de uma suposta competência intrínseca para atividades sociais, e no ideal de solidariedade.

Ponderam, contudo, fazendo referência a Luis Felipe Miguel que tal pode se enquadrar nas críticas endereçadas a vertente feminista chamada "ética do cuidado". Isto é, há um obscurecimento dos motivos da ausência de preocupação com a área social pela administração pública. Daí porque se as mulheres atuam em maior medida nessas áreas não se é em razão de uma identificação, mas sim, em virtude de não haver outra opção de inserção senão essa. ${ }^{86}$

Ressalvam, contudo, que os Conselhos foram inscritos na Constituição como resultado de uma luta travada pelos movimentos sociais. E, tal como o movimento feminista, buscou-se deslocar determinadas questões do campo privado para o de responsabilidade política. São questões que levam as autoras a concluir não ser possível desvincular os

85 COSTA, D. M. Capacitação de líderes femininas: reflexões sobre a experiência do IBAM. Revista Estudos Feministas, Florianópolis, v. 9, n. 1, p. 231-224, 2001.

86 MIGUEL, L. F. Representação política em 3-D: elementos para uma teoria ampliada da representação política. Revista Brasileira de Ciências Sociais, ano XVIII, n. 51, p. 123-140, 2003. 
Conselhos com as áreas sociais e o movimento feminista, de modo que a presença significativa das mulheres, na concepção das autoras "indica também o papel particular que elas vêm desempenhando na efetivação de direitos sociais cuja ausência responde pelas dificuldades das mulheres de saírem para o mundo privado" ${ }^{87}$

\section{5. À guisa de conclusões: ainda o homem no espaço público e a mulher no espaço privado}

A narrativa acima trouxe à luz a posição social distinta que compartilham homens e mulheres, essas como dominadas e aqueles como dominantes.Enquanto a virilidade representa a dominação masculina, a feminilidade se manifesta pela submissão, fragilidade, delicadeza. Enquanto às mulheres se atribui a vida doméstica, os homens têm o domínio da vida pública. É, assim, a composição da sociedade em que homens dominam e mulheres são submetidas, homens controlam e mulheres são controladas. A partir do século $X X$ a construção feminista vai de fronte à concepção de que a natureza tem o controle sobre o "destino" da mulher. O grande valor do feminismo, nesse sentido, foi em introduzir uma revolução na concepção da relação entre os sexos, por entender que essa relação pode ser objeto de uma ação transformadora. ${ }^{88}$

Essa revolução implica, necessariamente, na superação da relação público/homem e privado/mulher. Daí, porque

87 LÜCHMANN, L. H. H.; ALMEIDA, C. C. R. A representação política das mulheres nos Conselhos Gestores de Políticas Públicas. Revista Katálysis, v. 13, n. 1, p. 86-94, 2010,

88 COLLIN, Françoise. Diferença dos sexos (teorias da). In: HIRATA, Helena; e outras. (org.). Dicionário Crítico do Feminismo. São Paulo: Editora UNESP, 2009. p. 61. 
para a consecução de tal desiderato é necessária a participação feminina no campo público por excelência, o político. No entanto, não só a representação política foi fundada em uma perspectiva de total exclusão às mulheres, bem como se atrelou a representação à ideia de propriedade, o que comportou exclusões de outros sujeitos. Por isso não é de se admirar a dificuldade das mulheres ascenderem a esse espaço. Acresça-se a isso o fato da relação cultural arraigada a ideia de mulher-doméstica, o que faz com que ela tenha desvantagem em uma concorrência eleitoral. Exemplo recente disso é a notícia veiculada na revista Veja acerca da então quase primeira-dama, Marcela Temer, cujo título "bela, recatada e do lar".

Por isso, não é de se admirar a dificuldade das mulheres encontrarem seu espaçono parlamento, e no poder executivo. Por outro lado, despontou nos últimos anos um novo espaço político, de representação, no qual as mulheres puderam se inserir. Trata-se das inovações democráticas, instrumentalizadas desde de Promulgação da Constituição Cidadã. Os estudos trazidos no ensaio revelaram que há prevalência de participação feminina nas Conferências Nacionais, mas especialmente nos Conselhos Gestores locais. A priori, tais resultados despontam como grandes conquistas femininas. No entanto, alguns elementos fornecidos ensejaram debates críticos por parte da doutrina.

Os autores estudados destacam que a atuação feminina se dá de forma mais incisiva na área social, bem como há, igualmente, uma concepção de que é incumbência das mulheres tal responsabilidade. ${ }^{89}$ As justificações apontadas pelos autores são duas.

89 LÜCHMANN, L. H. H.; ALMEIDA, C. C. R. A representação política das mulheres nos Conselhos Gestores de Políticas Públicas. RevistaKatálysis, v. 13 , n. 1, p. 86-94, 2010, 
A primeira explicação, é a relação que existe entre área social e afazeres mais privados, do qual emergiria a relação com o gênero feminino, em contraposição às questões públicas. A segunda explicação resta no fato de ordinariamente as questões sociais serem relegadas pela administração. Assim, diante da falta de interesse dos homens sobre o tema, as mulheres podem militar nessas causas.

De uma maneira ou de outra, percebe-se que a lógica da distinção de gênero no qual se condiciona a mulher a uma situação de submissão segue presente. Seja pela contínua relação da mulher com o privado e seu distanciamento daquilo que é público, seja pela impossibilidade da mulher discutir questões que não sejam aquelas que não são do interesse do homem. Embora a mulher assuma papel de representação - que a permite assumir funções que no locus tradicional de representação ainda não tem espaço -, ela ainda não consegue se distanciar da relação dominante e dominada. A ocupação de espaços públicos pelas mulheres traz em si a ocupação pública para tratar de temas domésticos. Em síntese: leva-se para a vida pública discussões domésticas e privadas. A quebra e a visão mulher enquanto pessoa capaz de discutir o "bem comum do povo", cuja virtuosidade sempre foi restrita ao homem, segue presente.

Vale finalmente recordar que nenhuma mulher teve voz na elaboração das normas sob as quais vivem hoje homens e mulheres na visão de Catharine MacKinnon. ${ }^{90} \mathrm{~A}$ isonomia formal não resume a ideia de igualdade em um Estado Democrático de Direito. Em uma sociedade que tem como objetivo a inclusão, é necessário atentar à condição da mulher, grupo historicamente subjugado, excluído e opri-

90 MACKINNON, Catharine A. Reflections on Sex Equality under Law. The Yale Law Journal, Vol. 100, No. 5, Centennial Issue. mar., 1991. p. 1281. Disponível em: http://www.jstor.org/stable/796693. Acesso em 16.11.2015. 
mido. A proteção dos direitos fundamentais das mulheres é essencial a uma sociedade livre, justa, solidária e plural. Não se pode ignorar, de outro modo, que o fato per si da participação da mulher enquanto representante comporta um avanço no caminho de um empoderamento, cujas portas seguem fechadas nos locais de representação tradicionais.

\section{Referências}

ALMEIDA, Carla; TATAGIBA, Luciana. Os conselhos gestores sob o crivo da política: balanços e perspectivas. Serv. Soc. Soc., São Paulo, n. 109, p. 68-92, mar. 2012. Disponível em: <http://www.scielo.br/scielo.php?script=sci arttext\&pid=S0101-66282012000100005\&lng =en\&nrm $=\mathrm{i}$ so>. Acesso em 19.maio.2016. http://dx.doi.org/10.1590/ S0101-66282012000100005.

APFELBAUM, Erika. Dominação. In: HIRATA, Helena; e outras. (org.). Dicionário Crítico do Feminismo. São Paulo: Editora UNESP, 2009. p. 76-80.

AVRITZER, L. Conferências nacionais: Ampliando e redefinindo os padrões de participação social no Brasil. IPEA: Instituto de Pesquisa Econômica Aplicada, 2012.

BEAUVOIR, Simone. O Segundo Sexo. I. Fatos e Mitos. / Tradução de Sérgio Milliet. 4. ed. São Paulo: Difusão Européia do Livro, 1970. p. 9-10.

BONAT, Debora. PEIXOTO, Fabiano Hartmann. O incremento da cidadania através do reforço da participação popular e a crescente judicialização da política. Revista Brasileira de Estudos Políticos. Belo Horizonte, n. 112, pp. 109-146, jan./jun. 2016

BRASIL. Arena da Participação Social. Disponível em: http:/ / www.secretariageral.gov.br/participacao-social/politica. Acesso em 26/07/2015. 
CHAUÍ, Marilena. Participando do Debate sobre Mulher e Violência. In: CHAUÍ, Marilena; PAOLI, Maria Celia. (Org.). Perspectivas Antropológicas da Mulher 4. Rio de Janeiro: Zahar, 1985. p. 38-39 e p. 45.

COELHO, V. S. P.; FAVRETO, A. Conexões entre participação, democracia e desenvolvimento: investigação dos impactos políticos e distributivos. In: GURZA LAVALLE, A. (Org.). O horizonte da política: Questões emergentes e agendas de pesquisa. Questões emergentes e agenda de pesquisa. São Paulo: Unesp, 2012.

COLLIN, Françoise. Diferença dos sexos (teorias da). In: HIRATA, Helena; e outras. (org.). Dicionário Crítico do Feminismo.São Paulo: Editora UNESP, 2009. p. 59-61.

CORRÊA-PINTO, Maria Conceição. A Dimensão Política da Mulher. São Paulo: Edições Paulinas, 1992. p. 50.

COSTA, D. M. Capacitação de líderes femininas: reflexões sobre a experiência do IBAM. Revista Estudos Feministas, Florianópolis, v. 9, n. 1, p. 231-224, 2001.

COSTA, Pietro. Poucos, muitos, todos: lições da história da democracia. Curitiba: Editora UFPR, 2012.

DELPHY, Christine. Patriarcado (teorias do). In: HIRATA, Helena; e outras. (org.). Dicionário Crítico do Feminismo. São Paulo: Editora UNESP, 2009. p. 173-178.

FOUGEYROLLAS-SCHWEBEL, Dominique. Movimentos feministas. In: HIRATA, Helena; e outras. (org.). Dicionário Crítico do Feminismo. São Paulo: Editora UNESP, 2009. p. 144-145.

GUIMARÃES, Lívia. Hume e o feminismo. In: BORGES, Maria de Lourdes; TIBURI, Márcia. (Org.). Filosofia: machismos e feminismos. Florianópolis: Ed. da UFSC, 2014. p. 107-127. 
GURZA LAVALLE, A.; ARAÚJO, C. Ofuturo da representação: nota introdutória.Lua Nova, São Paulo, n. 67, p. 9-13, 2006.

GURZA LAVALLE, A.; HOUTZAGER, P. P.; CASTELLO, G. A construção política das sociedades civis. In: GURZA LAVALLE, A. (Org.). O horizonte da política. Questões emergentes e agenda de pesquisa. São Paulo: Unesp, 2012.

GURZA LAVALLE, Adrian. Após A Participação: Nota Introdutória. Lua Nova, São Paulo, 84: 13-23, 2011.

GURZA LAVALLE, Adrian; ISUNZA, Ernesto. Representación y participación en la crítica democrática. Desacatos (CIESAS), v. 49, p. 10-27, 2015, p.17.

HEINEN, Jacqueline. Políticas sociais e familiares. In: HIRATA, Helena; e outras. (org.). Dicionário Crítico do Feminismo. São Paulo: Editora UNESP, 2009. p. 190.

HELD, David. La democracia y el orden global. Del estado moderno algobiernocosmopolita.Barcelona: Paidos, 1997,p.30.

HOBBES, T. O leviatã. São Paulo: Abril Cultural, 1974. (Coleção Os Pensadores

HOLLANDA, Cristina Buarque de. Modos de representação política. Belo Horizonte: Editora UFMG; Rio de Janeiro: IUPERJ, 2009.

HUME, David. Investigações sobre o entendimento humano e sobre os princípios da moral. Tradução de José Oscar de Almeida Marques. São Paulo: Editora Unesp, 2004. p. 251-252. IPEA. Relatório de Pesquisa de Conselhos Nacionais de Politicas Públicas. Disponível em: http:/ / www.ipea.gov.br/participacao/images/pdfs/relatoriofinal_perfil_conselhosnacionais.pdf 
KANT, Immanuel. Observações sobre o sentimento do belo e do sublime. Seguido de Ensaio sobre as Doenças da Cabeça. Tradução de Pedro Panarra. Lisboa: Edições 70, 2015. p. 37 e p. 57-73. LAMOREUX, Diane. Público/privado. In: HIRATA, Helena; e outras. (org.). Dicionário Crítico do Feminismo. São Paulo: Editora UNESP, 2009. p. 211.

LIMA JUNIOR, Olavo Brasil de. Instituições Políticas Democráticas: o segredo da legitimidade. Rio de Janeiro: Jorge Zahar editor, 1997

LOCKE, John.Segundo tratado sobre o governo. Clube do livro liberal, 2002.

LOPES. Os Conselhos de Participação popular. A validade jurídica de suas decisões. Disponível em: http:/ / www.revistas.usp.br/rdisan/article/viewFile/13073/14875. Acesso em: 21/05/2016.

LÜCHMANN, L. H. H. A representação no interior das experiências de participação. Lua Nova, São Paulo, n. 70, p. 139-170, 2007.

LÜCHMANN, L. H. H.; ALMEIDA, C. C. R. A representação política das mulheres nos Conselhos Gestores de Políticas Públicas. Revista Katálysis, v. 13, n. 1, p. 86-94, 2010,

LÜCHMANN, L. H.; BORBA. A representação politica nos Conselhos [T] Gestores de Políticas Públicas. Disponível em: https:/ / www12. senado.leg.br/publicacoes/estudos-legislativos/tipos-de-estudos/textos-para-discussao/td158

LUCHMANN, Lígia Helena Hahn. Associações, participação e representação: combinações e tensões. Lua Nova, São Paulo, n. 84, p. 141-174, 2011 . Disponível em:<http:// www.scielo.br/scielo.php?script=sci_arttext\&pid=S0102-

MACKINNON, Catharine A. Reflections on Sex Equality under Law.The Yale Law Journal, Vol. 100, No. 5, Centennial 
Issue. mar., 1991. p. 1281. Disponível em: http:/ / www.jstor. org/stable/796693. Acesso em 16.novembro.2015.

MANIN, Bernard. La democracia de los modernos. Los principiosdelgobierno representativo. Revista Sociedad, Buenos Aires, 6, 1995.

MANN, L. H. H.; ALMEIDA, C. C. R. A representação política das mulheres nos Conselhos Gestores de Políticas Públicas. Revista Katálysis, v. 13, n. 1, p. 86

MATHIEU, Nicole-Claude. Sexo e gênero. In: HIRATA, Helena; e outras. (org.). Dicionário Crítico do Feminismo. São Paulo: Editora UNESP, 2009. p. 223.

MENDONÇA, M. P. Participação social: nenhum passo atrás! Disponivel em: <http:/ / www.ipea.gov.br/participacao/noticiasmidia/participacao-institucional/1185-participacao-social-nenhum-passo-atras>. Acesso em: 18/11/2015.

MIGUEL, L. F. Representação política em 3-D: elementos para uma teoria ampliada da representação política. Revista Brasileira de Ciências Sociais, ano XVIII, n. 51, p. 123-140, 2003.

MILL, John Stuart. The Subjection of Women. Kindle Edition. London, 1869. p. 1-7; p. 30.

MOLINIER, Pascale; WELZER-LANG, Daniel.Feminilidade, masculinidade, virilidade. In: HIRATA, Helena; e outras. (org.). Dicionário Crítico do Feminismo. São Paulo: Editora UNESP, 2009. p. 101-106.

MUDANÇA, O Brasil da. Disponível em: <http://www. brasildamudanca.com.br/participacao-e-transparencia/ participacao-e-transparencia>. Acessoem: 27/7/2016.

PAOLI, M. C. Movimentos sociais no Brasil: em busca de um estatuto político. In: HELLMANN, M. (Org.). Movimentos sociais e democracia no Brasil. São Paulo: Marco Zero; IldesFes, 1995. p. 25-55. 
PAOLI, Maria Celia. Mulheres: lugar, imagem, movimento. In: CHAUÍ, Marilena; PAOLI, Maria Celia. (Org.). Perspectivas Antropológicas da Mulher 4. Rio de Janeiro: Zahar, 1985. p. 66-68.

PATEMAN, Carole. O Contrato Sexual. Tradução de Marta Avancini. Rio de Janeiro: Paz e Terra, 1993. p. 240-243.

PATEMAN, Carole. Participação e teoria democrática. Tradução Luiz Paulo Rouante. Rio de Janeiro: Paz e Terra, 1992.

PEDRA, Adriano Sant'Ana. Participação popular no poder local: o papel do cidadão no aprimoramento das decisões do Executivo e do Legislativo municipal. Revista Brasileira de Estudos Políticos, Belo Horizonte, n. 100, p. 29-56, jan./ jun. 2010, p. 30.

PERROT, Michelle. História (sexuação da). In: HIRATA, Helena; e outras. (org.). Dicionário Crítico do Feminismo. São Paulo: Editora UNESP, 2009. p. 115.

PIRES, R. R. C.; VAZ, A. C. N. Para além da participação: interfaces socioestatais no governo federal. Lua Nova, São Paulo, n. 93, p. 61-91, 2014.

PISARELLO, Gerardo. Um largo termidor. Historia e critica do constitucionalismo antidemocrático. Quito: Corte Constitucional para el partido de transicion, 2012. p.16.

PITKIN, H. F. El concepto de representacion. Madrid: Centro de Estúdios Constitucionales, 1985.

PITKIN, H. F. Representação: palavras, instituições, ideias. Lua Nova, São Paulo, n. 67, p. 15-47, 2006, p.26.

POGREBINSCHI, T.; SANTOS, F. Participação como representação: O impacto das Conferências Nacionais de Políticas Públicas no Congresso Nacional. Revista de Ciências Sociais, Rio de Janeiro, v. 54, n. 3, p. 259-305, 2011. 
SAFFIOTTI, Heleieth. Gênero, patriarcado e violência. 2. ed. São Paulo: Expressão Popular / Fundação Perseu Abramo, 2015. p. 47 e p. 129.

SALGADO, Eneida Desiree. Constituição e Democracia - Tijolo por tijolo em um desenho (quase) lógico:Vinte anos de construção do projeto democrático brasileiro. Belo Horizonte: Fórum, 2007. 280.

SANTOS, Boaventura de Souza e AVRITZER, Leonardo. Introdução: para ampliar o cânone democrático. In: Democratizar a democracia: os caminhos da democracia participativa. Rio de Janeiro: Civilização Brasileira, 2002.

SANTOS, Magda Guadalupe dos. O feminismo na história: suas ondas e desafios epistemológicos. In: BORGES, Maria de Lourdes; TIBURI, Márcia. (Org.). Filosofia: machismos e feminismos. Florianópolis: Ed. da UFSC, 2014. p. 129-130.

SCHERER, Berta Rieg. Sobre o caráter sexual da mulher e do homem em Kant. In: BORGES, Maria de Lourdes; TIBURI, Márcia. (Org.). Filosofia: machismos e feminismos. Florianópolis: Ed. da UFSC, 2014. p. 23-27.

SCHWARZER, Alice. As feministas são piratas.In: SOLIZ, Neusa. (Org.) A mulher no século XXI: um estudo de caso, a Alemanha. Tradução de Neusa Soliz. Rio de Janeiro: Espaço e Tempo; São Paulo: Instituto Goethe, 1988. p. 136-138.

SHCULZ, Rosangela; Dieni Rodrigues; MENDES, Ana Cristina. A atuação feminina nos Conselhos da Mulher: um estudo dos Conselhos de Pelotas e de Santa Cruz do Sul/RS. Revista Debates, Porto Alegre, v.7, n.3, p.149-168, set.-dez. 2013.

SOUZA, Marcius F. B. de. A Participação das Mulheres na elaboração da Constituição de 1988. In: Constituição de 1988: O Brasil 20 anos depois. Os Alicerces da Redemocratização (Vol. 1). Brasília: Senado Federal, Instituto legislativo brasileiro, 2008. Disponível em: <http://www12.senado.gov. $\mathrm{br} /$ publicacoes/estudos-legislativos/tipos-de-estudos/ outras-publicacoes/volume-i-constituicao-de-1988/ principios-e-direitos-fundamentais-a-participacao-das-mulheres- 
-na-elabor acao-da-constituicao-de-1988/view>. Acesso em 16.11.2015.

SOUZA, Patrícia Verônica Nunes Carvalho Sobral de; CARDOSO, Henrique Ribeiro. Participação popular e controle social: uma análise dos conselhos públicos à luz da teoria habermasiana. Revista Brasileira de Estudos Políticos, Belo Horizonte, n. 116, pp. 309-349, jan./jun. 2018

SOW, Marilene Mendes. A Participação Feminina na Construção de um Parlamento Democrático. E-legis, n. 05, p. 79-94, 2. semestre, 2010.

URBINATI. O que torna a representação democrática?. Encontro Anual da American Political Science Association (Apsa), Washington (EUA), setembro de 2005.

VARIKAS, Eleni. Igualdade. In: HIRATA, Helena; e outras. (org.). Dicionário Crítico do Feminismo.São Paulo: Editora UNESP, 2009. p. 117.

WOLLSTONECRAFT, Mary. Vindication of the Rights of Woman. Kindle Edition. 1792. p. 9-15. 
Recebido em 27/08/2019

Aprovado em 28/01/2020

Lígia Maria Silva Melo Casimiro

E-mail: meloligia@gmail.com

Ana Cristina Aguilar Viana

E-mail:anacristina_av@hotmail.com

Letícia Regina Camargo Kreuz

E-mail: leticiakreuz@gmail.com 
